Journal of Agriculture and Social Research (JASR) Vol. 8, No. 2, 2008

\title{
BUILDING FARMERS' KNOWLEDGE IN CASSAVA VALUE ADDITION FOR IMPROVED RURAL LIVELIHOODS IN ABIA STATE: ISSUES FOR POLICY CONSIDERATION
}

\author{
EKWE, K.C., NWAKOR F.N., IRONKWE A.G AND AMANGBO L.E.F \\ National Root Crops Research Institute Umudike, \\ P.M.B. 7006 Umuahia, Abia State, Nigeria.
}

\begin{abstract}
Attempts by National Root Crops Research Institute, Umudike, Nigeria to add value to cassava have led to development of several products such as cake, bread, chin-chin from cassava in order to diversify its utilization. . The Institute embarked upon a rural empowerment campaign through promotion, popularization and training of rural households on the cassava value addition technologies. About 10 rural communities in Abia State, Nigeria have benefited from this participatory training programme. A study was carried out in 2006 in Abia State to examine the effects of the training programme on the livelihoods of the rural households in the study area. A total of 150 respondents from four Local Government Areas where the training workshops held were purposively sampled for the study. Data were collected with use of structured questionnaire and analyzed using means, percentages, tables and frequencies. Results indicated that use of acquired knowledge on cassava value addition has high influence on farmers' livelihoods in Arochukwu (3.02), but moderate influences on their livelihoods in Umunneochi(2.01), Umuahia(1.9) and Ukwa East(1.7) LGAs as evidenced by availability of different cassava food forms, earning of extra incomes, self employment, as well as poverty reduction in the house holds. There is therefore the need to explore and sustain this rural empowerment strategy by providing the necessary policy leverage and support that will facilitate efforts and activities of government agencies to enhance the livelihoods of rural farmers.
\end{abstract}

Key words: Building, Knowledge, Value addition, Livelihoods, Policy

\section{INTRODUCTION}

The presence of high level of hydrogen cyanide $(\mathrm{HCN})$ in roots of bitter cassava makes processing indispensable before cassava can be consumed by human being. Further more, processing operation in cassava has essentially created array of opportunities for enhancing the worth, quality and usefulness of primary products of cassava. Thus, the processes of enhancing cassava's worth, quality and usefulness are called value addition. Hence through processing and diversification of uses cassava can be transferred into wide range of food forms in order to increase its consumption, increase the shelf life of the products, improve product palatability enhance market value, reduce post harvest losses, facilitate transportation and provide raw materials to cassava based agro industries (IITA, 1990).

Cassava is an indispensable staple food for over 500 million people in tropical Africa but particularly in West African sub-region. It is a major source of energy with very high food security value similar to most cereal crops (Oguntona 1999, Achinewhu and Onwuama, 2000). Cassava possesses special attributes, which include ability to make returns of root yield even at extreme stress conditions; tolerance to unfavourable 


\section{Journal of Agriculture and Social Research (JASR) Vol. 8, No. 2, 2008}

conditions like low soil $\mathrm{PH}$, marginal soil fertility, and drought; suitability to various farming and food systems in Africa, minimal external input requirements, all year round availability as well as efficient production food energy. These attributes single cassava out as ideal crop for the tropics (Beeching et al 2000, Awah and Tumanteh 2001).

Alternative uses of cassava through value addition has resulted in emergence of wide food recipes from cassava through processing which involves conversion of edible food into another form more acceptable or more convenient to the consumer (Malcolm 1977). National Root Crops Research Institute (NRCRI) Umudike developed technologies in cassava utilization aimed at diversifying the uses of cassava in Nigeria. Some value added products from cassava include Cassava flour, Cassava starch, Cassava bread, Cassava chin-chin, Cassava chips, Cassava flakes, Cassava odourless fufu, Cassava doughnut, Cassava cake, Cassava biscuit and Cassava salad cream. The value addition technology in cassava possesses enormous potentiality for increasing cassava consumption, diversifying its uses as well as using same to enhance livelihoods of farm families through providing opportunities for employment; micro agro enterprises development income and boosting economy of rural households (Nwakor et.al, 2007).

Again, Amamgbo, et al (2006) observed that diversification of cassava use promises high potentiality for wedging hunger, alleviating poverty as well as enhancing the livelihoods of many rural farm households. Thus development and dissemination of cassava value adding technologies by National Root Crops Research Institute; Umudike is timely, appropriate and vital in the current effort to improve the livelihoods of rural households. This study was therefore designed to determine the effect of training workshop on cassava value addition on livelihoods of rural households in Abia State.

\section{METHODOLOGY}

The study was carried out in Abia State. Four local government areas (LGAs) of Abia state were purposively selected for the study area due to their involvement in the training workshop. The L.G.As involved in the study included; Arochukwu, Ukwa East, Umuahia South and Umunneochi where some women groups have received trainings on the cassava value adding technologies for production of the various food forms. In 2005, a total of 391 participants from Arochukwu ( 73 ), Ukwa East (80), Umuahia South (178) and Umunneochi (60) were involved in participatory training workshops on the use of cassava flour for production of a range of end products such as cakes, chin-chin, doughnut etc.

In 2006, a field survey was conducted in the four local government areas (LGAs) where the training workshops held to ascertain the influence of use of knowledge acquired on cassava value addition on selected indicators of farmers' livelihoods in the study area. The selected livelihoods indicators considered in the study included potentialities for a) making different food forms, b) income generation, c) self employment, d) hunger reduction and e) poverty reduction. By simple random sampling technique, 50 women farmers who took part in the training workshop were selected from each LGA. This summed up to a sample size of 200 respondents for the study. Using structured questionnaires data concerning income generation, poverty reduction as well as self employment potentialities of the cassava value addition technologies were collected from the respondents.

Data collected were analyzed by descriptive statistics, such as frequencies, tables, means and percentages. Also, a 4-point Likert measurement was employed to assess the 


\section{Journal of Agriculture and Social Research (JASR) Vol. 8, No. 2, 2008}

influence of use of the acquire knowledge in cassava value addition on the selected farmers' livelihoods indicators. The Likert's measurement was scored as follows: 'No influence' $=1$; 'little influence' $=2$; 'moderate influence' $=3$; 'much influence' $=4$ point. The mean score for each variable was obtained and used in categorizing the influences as high, moderate and low. The categories were obtained by dividing the 3 spaces in the range (1-4) into 3 parts as employed by Onu and Obibuaku (1987). This gave a unit interval of 1 . The unit interval was then subtracted successively from the mazimu score (4) to obtain lower class marks of 3.00, 1.99 and 0 respectively. On this basis therefore, the knowledge on cassava value addition $\mathrm{n}$ farmers'; livelihood were classified as follows: 'High influence' $=4-3$; Moderate influence; $2.99-1.99$. Little influence $=<1.99$

\section{RESULTS AND DISCUSSION}

Results in Table 1 disclosed that the participatory training workshop provided opportunities for the rural women groups to acquire and build the necessary technical knowledge in diversifying cassava utilization through value addition techniques. Majority of respondents in Arochukwu (74\%) Ukwa East (64\%), Umuahia (32\%) and Umunneochi $(84 \%)$ acquired the skill for producing odourless fufu for cassava. Also, on the average, $55 \%$ of respondents in the study area acquired the knowledge for production of cassava flour while $48 \%, 42 \%, 41 \%$ of the respondents acquired skills and knowledge for making of cassava chips, cassava bread and cassava flakes respectively. By implications knowledge acquired and developed in cassava value addition through the training workshop has become tremendous assets and empowerment for rural households to even engage in micro agro enterprises.

In view of this, results in Table 2 revealed that with the use of technical knowledge acquired, $63 \%$, of the respondents could make deferent food forms from cassava for household consumption, while the use of the knowledge among the respondents has brought about reductions in hunger (57\%) and poverty (44\%) among the rural households in the study area. Also, $19 \%$ of the respondents have already secured self employment as a result of the technical skills and knowledge acquired in the cassava value addition techniques.

Table 3 showed the influence of use of acquired knowledge in cassava value addition on selected livelihood indicators among rural households in Abia State. Results showed that the influence was relatively high in individual livelihood indicators such as making different food forms from cassava (3.1), earning extra income (2.8), fighting hunger (3.1), self employment (3.1) and poverty reduction (3.0) among households in Arochukwu zone. However, the influence of acquired knowledge in cassava value addition was relatively moderate in same livelihood indicators among households in Umunneochi (2.0), Umuahia (1.9), and Ukwa East (1.7) zones. The influences of the acquired knowledge in cassava value addition livelihoods of households in Arochukwu zone was more impressive and higher than other zones probably because of the repeated training workshops organized for women groups in that zone. Same workshops have not been repeated in other zones.

Again, Table 4 showed that in Arochukwu that $36 \%$ of the respondents earned over N15,000 annually from cassava value added products while $20 \%$ and $8 \%$ earned similar amount of income in Ukwa East and Umuahia LGAs respectively. However, the respondents enumerated some constrained associated with the use of cassava value 
addition technology. Results in Table 5 shows that $76 \%$ of respondents indicated lack of capital as a major constraint while lack of appropriate equipment (74\%), lack of interest $(43 \%)$, no market $(27 \%)$ as well as lack of sufficient skills $(48 \%)$ where other constraints mentioned.

\section{CONCLUSION AND RECOMMENDATIONS}

Results from the study showed that there were substantial effects of the newly acquired knowledge in cassava value addition among rural households in the study area as evidenced in availability of diverse food forms of cassava, income generation from the cassava value added products, self employment as well as reduction in household poverty and hunger. There is therefore the need to protect, sustain and explore this rural empowerment strategy by providing the necessary policy leverage and support that will facilitate efforts of government agencies enhancing the livelihoods of rural households. Also, policy framework and guidelines should be stipulated which shall provide a congenial and enabling environment for involvement of other stakeholders such as extension and input agencies in building formidable knowledge in cassava value addition among farmers in Abia State. Also, appropriate policy instruments which shall source and with the provide farmers with credits requires in developing micro agro enterprise opportunities in cassava value addition. Moreover, low cost and locally sourced processing utensils need to be developed and made readily available to rural households.

Table 1: Percentage Distribution of Respondents according to Participation in Knowledge Acquisition on Cassava Value Addition

\begin{tabular}{|c|c|c|c|c|c|}
\hline Technology & $\underset{\%}{\text { Arochukwu }}$ & $\begin{array}{c}\text { Ukwa East } \\
\%\end{array}$ & $\underset{\%}{\text { Umuahia }}$ & $\begin{array}{c}\text { Umunneochi } \\
\%\end{array}$ & Mean(\%) \\
\hline $\begin{array}{l}\text { Cassava } \\
\text { flour }\end{array}$ & 54 & 62 & 50 & 54 & 55 \\
\hline $\begin{array}{l}\text { Odourless } \\
\text { fufu }\end{array}$ & 74 & 64 & 32 & 84 & 63.5 \\
\hline $\begin{array}{l}\text { Cassava } \\
\text { starch }\end{array}$ & 52 & 44 & 14 & 16 & 32.5 \\
\hline $\begin{array}{l}\text { Cassava } \\
\text { chips }\end{array}$ & 58 & 22 & 12 & 100 & 48 \\
\hline $\begin{array}{l}\text { Cassava } \\
\text { flakes }\end{array}$ & 44 & 12 & 8 & 100 & 41 \\
\hline $\begin{array}{l}\text { Cassava } \\
\text { bread }\end{array}$ & 56 & 28 & 32 & 50 & 41.5 \\
\hline
\end{tabular}

Source: Field Survey, 2006.

Table 2: Percentage Distribution of Respondents based on their Benefit of the Cassava Value Addition Technology

\begin{tabular}{lccccc}
\hline Benefit & $\begin{array}{c}\text { Aro-chukwu } \\
(\mathbf{\%})\end{array}$ & $\begin{array}{l}\text { UkwaEast } \\
(\%)\end{array}$ & $\begin{array}{l}\text { Umuahia } \\
(\mathbf{\%})\end{array}$ & $\begin{array}{l}\text { Umunneochi } \\
(\mathbf{\%})\end{array}$ & $\begin{array}{l}\text { Mean } \\
(\%)\end{array}$ \\
\hline Making different & 54 & 66 & 62 & 68 & 62.5 \\
food forms & & & & & \\
Self employment & 32 & 24 & 18 & 0 & 18.5 \\
Hunger reduction & 50 & 42 & 50 & 82 & 56.5 \\
\hline
\end{tabular}


Journal of Agriculture and Social Research (JASR) Vol. 8, No. 2, 2008

\begin{tabular}{llllll}
\hline Poverty reduction & 54 & 66 & 48 & 8 & 44.0 \\
\hline
\end{tabular}

Source: Field Survey, 2006. 
Table 3: Likert's 4-point measurement of Influence of Use acquired knowledge on Cassava Value Addition on selected Livelihoods among Rural Women Farmers in the Study Area.

\begin{tabular}{|c|c|c|c|c|c|c|c|c|c|c|c|c|c|c|c|c|c|c|c|c|c|}
\hline \multirow{2}{*}{$\begin{array}{c}\text { Selected } \\
\text { livelihoods } \\
\text { indicators }\end{array}$} & \multicolumn{5}{|c|}{ Arochukwu } & \multicolumn{5}{|c|}{ Ukwa East } & \multicolumn{5}{|c|}{ Umuahia } & \multicolumn{5}{|c|}{ Umu nne ochi } & \multirow{2}{*}{\begin{tabular}{|c} 
Mean \\
$\begin{array}{c}\text { Grand } \\
\text { mean }\end{array}$ \\
Max= \\
4
\end{tabular}} \\
\hline & $\begin{array}{l}\mathrm{Nn} \\
(1)\end{array}$ & $\begin{array}{l}\mathrm{Lt} \\
2)\end{array}$ & $\begin{array}{c}M \\
d \\
(3)\end{array}$ & $\begin{array}{c}\mathrm{Mc} \\
\mathrm{h} \\
(4)\end{array}$ & $\begin{array}{c}\mathrm{Mn} \\
\operatorname{Max}= \\
4\end{array}$ & $\begin{array}{l}\mathrm{Nn} \\
(1)\end{array}$ & $\begin{array}{l}\mathrm{Lt} \\
(2)\end{array}$ & $\begin{array}{l}\mathrm{Md} \\
\text { (3) }\end{array}$ & $\begin{array}{l}\text { Mch } \\
(4)\end{array}$ & $\begin{array}{c}\mathrm{M} \\
\mathrm{n} \\
\mathrm{Ma} \\
\mathrm{x}= \\
4\end{array}$ & $\begin{array}{l}\mathrm{Nn} \\
(1)\end{array}$ & $\begin{array}{l}\mathrm{Lt} \\
(2)\end{array}$ & $\begin{array}{c}M \\
d \\
(3)\end{array}$ & $\begin{array}{c}\mathrm{Mc} \\
\mathrm{h} \\
(4)\end{array}$ & $\begin{array}{c}\mathrm{M} \\
\mathrm{n} \\
\mathrm{Ma} \\
\mathrm{x}= \\
4\end{array}$ & $\begin{array}{l}\mathrm{Nn} \\
(1)\end{array}$ & $\begin{array}{l}\mathrm{Lt} \\
(2)\end{array}$ & $\begin{array}{c}M \\
d \\
(3)\end{array}$ & $\begin{array}{l}\text { Mch } \\
\text { (4) }\end{array}$ & $\begin{array}{c}\mathrm{M} \\
\mathrm{n} \\
\mathrm{Ma} \\
\mathrm{x}= \\
4\end{array}$ & \\
\hline $\begin{array}{l}\text { Making } \\
\text { different food } \\
\text { forms }\end{array}$ & 10 & 2 & 11 & 27 & 3.1 & 22 & 24 & 3 & 1 & 1.7 & 22 & 11 & 9 & 8 & 2.1 & 17 & 33 & 0 & 0 & 1.7 & 2.2 \\
\hline $\begin{array}{l}\text { Generating } \\
\text { Extra Income }\end{array}$ & 8 & 9 & 20 & 13 & 2.8 & 35 & 7 & 7 & 1 & 1.2 & 29 & 12 & 8 & 1 & 1.6 & 48 & 2 & 0 & 0 & 1.2 & 1.7 \\
\hline $\begin{array}{l}\text { Fighting of } \\
\text { Hunger }\end{array}$ & 4 & 6 & 20 & 20 & 3.1 & 18 & 19 & 5 & 8 & 2.1 & 23 & 6 & 5 & 16 & 2.3 & 6 & 31 & 13 & 0 & 2.2 & 2.4 \\
\hline $\begin{array}{l}\text { Self Employ } \\
\text { ment }\end{array}$ & 6 & $\begin{array}{l}1 \\
0\end{array}$ & 15 & 19 & 3.1 & 21 & 19 & 4 & 6 & 1.9 & 30 & 9 & 4 & 7 & 1.3 & 48 & 1 & 1 & 0 & 1.0 & 1.8 \\
\hline $\begin{array}{l}\text { Poverty } \\
\text { Reduction }\end{array}$ & 7 & 6 & 19 & 18 & 3.0 & 23 & 19 & 2 & 6 & 1.8 & 22 & 9 & 5 & 14 & 2.2 & 45 & 4 & 1 & 0 & 1.1 & 2.0 \\
\hline Mean & & & & & 3.02 & & & & & 1.7 & & & & & 1.9 & & & & & 1.4 & 2.01 \\
\hline
\end{tabular}

Key 
Journal of Agriculture and Social Research (JASR) Vol. 8, No. 2, 2008

\author{
$\mathrm{Nn}=$ None \\ $\mathrm{Lt}=$ Little \\ $\mathrm{Md}=$ Moderate \\ Mch=Much \\ $\mathrm{Mn}=$ Mean
}


Journal of Agriculture and Social Research (JASR) Vol. 8, No. 2, 2008

Table 4: Percentage Distribution of Respondents Based on Income generated from Use of the Cassava Value Addition Technology

\begin{tabular}{lccccc}
\hline Income earning & $\begin{array}{c}\text { Arochukwu } \\
(\%)\end{array}$ & $\begin{array}{l}\text { UkwaEast } \\
(\%)\end{array}$ & $\begin{array}{l}\text { Umuahia } \\
(\%)\end{array}$ & $\begin{array}{l}\text { Umunneochi } \\
(\%)\end{array}$ & $\begin{array}{l}\text { Mean } \\
(\%)\end{array}$ \\
\hline Amount in $\mathrm{N}$ & & & & & 76 \\
$0-5,000$ & 42 & 80 & 84 & 98 & 3.5 \\
$6-10,000$ & 8 & 0 & 4 & 2 & 4.5 \\
$11-15,000$ & 14 & 0 & 4 & 0 & 16 \\
Above 15,000 & 36 & 20 & 8 & 0 & \\
\hline
\end{tabular}

Source: Field Survey, 2006.

Table 5: Percentage Distribution of Respondents according to the Constraints Militating Against Use of Acquired Knowledge in Cassava Value Addition.

\begin{tabular}{|c|c|c|c|c|c|}
\hline Benefit & $\begin{array}{c}\text { Arochukwu } \\
(\%)\end{array}$ & $\begin{array}{l}\text { Ukwa East } \\
(\%)\end{array}$ & $\begin{array}{l}\text { Umuahia } \\
(\%)\end{array}$ & $\begin{array}{l}\text { Umunneochi } \\
(\%)\end{array}$ & Mean (\%) \\
\hline Lack of capital & 78 & 88 & 60 & 84 & 76.0 \\
\hline $\begin{array}{ll}\text { Lack } & \text { of } \\
\text { equipment }\end{array}$ & 98 & 82 & 60 & 54 & 73.5 \\
\hline For processing & 10 & 92 & 10 & 60 & 43 \\
\hline No interest & 40 & 48 & 2.0 & 2.0 & 23 \\
\hline $\begin{array}{l}\text { Difficult } \\
\text { practice }\end{array}$ & 36 & 6 & 16 & 44 & 25.5 \\
\hline $\begin{array}{l}\text { Lack of skill and } \\
\text { others }\end{array}$ & 54 & 80 & 24 & 24 & 48 \\
\hline
\end{tabular}

Source: Field Survey, 2006.

REFERENCES:

Amamgbo L.E.F., Ekwe, K.C., Aeniedu C. (2000) Acceptance of instant odourless fufu and gari forms of NR8082 ASN $39^{\text {th }}$ proceeding Owerri.

Achinewhu, S.C. and Onwuama C.I (2001) Garification of Five Improved Cassava Cultivars in Nigeria and Physicochemical and Sensory Properties of Gari Yield. African Journal of Root and Tuber Crops.Vol.4,No.2

Awah, E.T and Tumanteh, A (2001) Cassava Based Cropping Systems And Use Of Inputss In Different Ecological Zones Of Central Africa. African Journal of Root and Tuber Crops.Vol.4,No.2

Beeching, J.R. Niger, T and Tohme, J. (2000). Post Harvest Physiological Deterioration of Cassava. Proceedings of $12^{\text {th }}$ Symposuim of International Society of Tropical Root Crop held in Tsuba, Japan September, 1016.

Internatinal Institute of Tropical Agriculture (1990).Annual Report for the Year 1990.

Malcoln C.B. (1977). Post Harvest Food Losses; Cornell University Press, New York.. 
Journal of Agriculture and Social Research (JASR) Vol. 8, No. 2, 2008

Nwakor, F.N., Ekwe, K.C., Amamgbo, L.E.F., Anyaegbunam, H.N. Ironkwe and Asumugha G.N. (2007). Annual Report of NRCRI, Umudike February, 2007.

Oguntona, E.B. (1986). Need for Consistency in Nigerian Agricultural Development Policy: Agricultural Development in Nigeria, Obafemi Awolowo University Press Pp 35-70.

Onu D.O and Obibuaku, L. (1987), Appraising performance of Interfering Variables in the Agricultural Development Programme of Imo State. A Mimeograph in the Department of Agric Extension, University of Nigeria Nsukka. P 21. 